
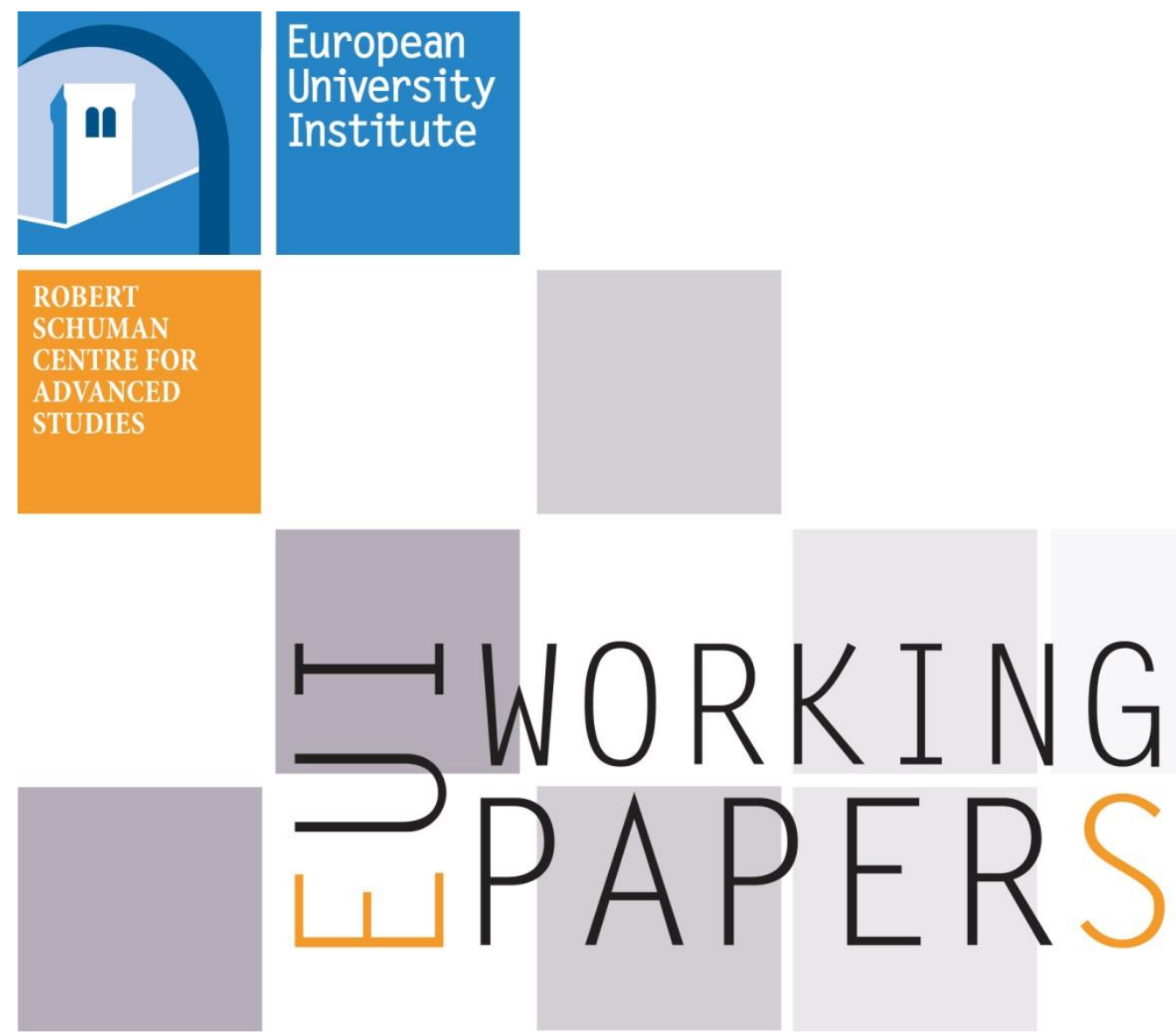

RSCAS 2014/128

Robert Schuman Centre for Advanced Studies Global Governance Programme-150

Patterns of International Organization Task Specific vs. General Purpose

Tobias Lenz, Jeanine Bezuijen, Liesbet Hooghe and Gary Marks 

European University Institute

Robert Schuman Centre for Advanced Studies

Global Governance Programme

\section{Patterns of International Organization \\ Task Specific vs. General Purpose}

Tobias Lenz, Jeanine Bezuijen, Liesbet Hooghe and Gary Marks

EUI Working Paper RSCAS 2014/128 
This text may be downloaded only for personal research purposes. Additional reproduction for other purposes, whether in hard copies or electronically, requires the consent of the author(s), editor(s). If cited or quoted, reference should be made to the full name of the author(s), editor(s), the title, the working paper, or other series, the year and the publisher.

ISSN 1028-3625

(C) Tobias Lenz, Jeanine Bezuijen, Liesbet Hooghe and Gary Marks, 2014

Printed in Italy, December 2014

European University Institute

Badia Fiesolana

I - 50014 San Domenico di Fiesole (FI)

Italy

www.eui.eu/RSCAS/Publications/

www.eui.eu

cadmus.eui.eu 


\section{Robert Schuman Centre for Advanced Studies}

The Robert Schuman Centre for Advanced Studies (RSCAS), created in 1992 and directed by Brigid Laffan since September 2013, aims to develop inter-disciplinary and comparative research and to promote work on the major issues facing the process of integration and European society.

The Centre is home to a large post-doctoral programme and hosts major research programmes and projects, and a range of working groups and ad hoc initiatives. The research agenda is organised around a set of core themes and is continuously evolving, reflecting the changing agenda of European integration and the expanding membership of the European Union.

Details of the research of the Centre can be found on:

http://www.eui.eu/RSCAS/Research/

Research publications take the form of Working Papers, Policy Papers, Distinguished Lectures and books. Most of these are also available on the RSCAS website:

http://www.eui.eu/RSCAS/Publications/

The EUI and the RSCAS are not responsible for the opinion expressed by the author(s).

\section{The Global Governance Programme at the EUI}

The Global Governance Programme (GGP) is research turned into action. It provides a European setting to conduct research at the highest level and promote synergies between the worlds of research and policy-making, to generate ideas and identify creative and innovative solutions to global challenges.

The GGP comprises three core dimensions: research, policy and training. Diverse global governance issues are investigated in research strands and projects coordinated by senior scholars, both from the EUI and from other internationally recognized top institutions. The policy dimension is developed throughout the programme, but is highlighted in the GGP High-Level Policy Seminars, which bring together policy-makers and academics at the highest level to discuss issues of current global importance.The Academy of Global Governance (AGG) is a unique executive training programme where theory and "real world" experience meet. Young executives, policy makers, diplomats, officials, private sector professionals and junior academics, have the opportunity to meet, share views and debate with leading academics, top-level officials, heads of international organisations and senior executives, on topical issues relating to governance.

For more information:

http://globalgovernanceprogramme.eui.eu 



\begin{abstract}
This paper surveys fundamental contrasts in the articulation of international authority using a new dataset, constructed by the authors, that estimates the composition and decision-making rules of 72 international organizations from 1950 to 2010 . We theorize that two modes of governance - general purpose and task specific - represent distinctive ways of organizing political life, and this has stark implications for the exercise of international authority. We engage theoretical perspectives that bridge rational and constructivist approaches to examine how general purpose and task specific international organizations exhibit systematic differences in their institutional configuration, delegation, pooling, and development.
\end{abstract}

\title{
Keywords
}

International organization, delegation, pooling, authority, autonomy 



\section{Introduction*}

There are many ways to reap scale beyond the national state - empires, leagues, confederations, alliances, and international agreements - but international governmental organizations are distinctive. They are voluntary (unlike empires and all other hierarchical forms of governance), have a differentiated and generally more permanent institutional structure (unlike alliances and international agreements), and have an independent capacity for rule making (unlike leagues or confederations). Beyond these characteristics, there is wide variation. Some international organizations (IOs) have just a few member states; others are global in their coverage. Some focus on a single policy area; others have extremely broad policy portfolios. Some have a diversified institutional architecture; others are fairly simple in their institutional organization. Some appear to be relatively fixed in their organization and membership, while others change considerably over time.

The premise of this article is that the diversity of international organization can be explained as a response to the tension between scale and community in the provision of public goods. On the one hand, interactions among national communities produce externalities and, therefore, demand for transnational public goods (Deutsch 1953; Marks 2012). International jurisdictions that have a capacity for continuous information gathering and negotiation are vital for managing problems that transcend national communities. Larger jurisdictions can provide pure public goods, including economic exchange, at lower cost, and they can internalize policy consequences over a larger population. From this standpoint international organizations can be conceived as functional institutions that reap the benefits of scale for the provision of public goods.

But the willingness to sustain an IO depends on more than its functional benefits. Governance is an expression of community and expresses the desire of territorially concentrated groups of people with distinctive histories, institutions and preferences to rule themselves. People care deeply about who exercises authority over them, and we argue that this exerts a powerful constraint on governance beyond the state (Hooghe/Marks 2009a). Community is much stronger within, than among, states. Hence the dilemma for governance among states is to gain the benefits of scale while adjusting governance to the shallowness of transnational community. To what extent are states willing to commit themselves to incomplete contracts that delegate authority over a broad, but unspecified, range of policy areas? How prepared are they to delegate authority to independent non-state actors? Under what circumstances will they be willing to bind themselves to majority rule?

Our argument is that there are two contrasting approaches to institutional cooperation among states (Hooghe/Marks 2003, 2010; Enderlein et al. 2010; Hasenclever et al. 1997; Peters et al. 2012, p. 18). The first reproduces general purpose government at the international level by engaging the manifold problems that confront a given set of countries as they interact. General purpose (Type 1) IOs express a sense of shared purpose among their members. They bundle the provision of public goods for a particular transnational community and, accordingly, they are broad in policy scope. Such IOs may deal with security issues alongside trade issues, or they may engage not just environmental problems for a given community, but a variety of other issues such as culture, transport, human rights, disease, or migration.

\footnotetext{
This paper is forthcoming as Tobias Lenz, Jeanine Bezuijen, Liesbet Hooghe, and Gary Marks, "Patterns of International Organization: Task Specific vs. General Purpose, Politische Vierteljahresschrift.

The authors acknowledge support from the European Research Council Advanced Grant \#249543 "Causes and Consequences of Multilevel Governance." Earlier versions of the paper were presented at an authors' workshop held in Potsdam in November 2013, the International Studies Association in Toronto, March 2014, and a workshop on "Multilevel Governance above the State" held in Delmenhorst, July 2014. We thank the participants at these events for comments, with special thanks to Thomas Gehring, Julia Gray, Yoram Haftel, Duncan Snidal, Jonas Tallberg, and Michael Zürn. This paper was prepared for a special issue on international organization for the Politische Vierteljahresschrift.
} 
Table 1: Modes of international organization

\begin{tabular}{cc}
\hline General purpose IO & Task specific IO \\
(Type 1 governance) & (Type 2 governance) \\
\hline broad policy scope & narrow policy scope \\
community driven & problem driven \\
bundle public goods & decompose public goods \\
\hline
\end{tabular}

The second approach is to decompose problems so that they can be handled independently. Task specific (Type 2) IOs are rooted not in shared communities, but in shared problems. Each task specific IO is created to solve a particular cooperation problem in a specific policy domain such as trade, air traffic control, food safety, or security. The idea is to parse policy problems into functionally discrete pieces which are connected only in the medium, but not in the short, term so that each may be dealt with in a separate organization (Simon 1996).

Our purpose in this article is to show a) that the tension between community and scale incentivizes the choice between general purpose and task specific governance and b) that this choice has fundamental consequences for institutional design. Task specific IOs have much larger memberships than general purpose IOs. They are much more likely to have majoritarian decision-making rules. Their institutional structure is simpler, and they tend to delegate less to non-state bodies. And they are much less likely to be reformed after they have been set up.

Beyond its validity, a theory can be valuable if it suggests that a phenomenon, which was taken for granted, is puzzling and worthy of explanation. Why are so many institutional features of international organizations - including the scale of their memberships, the scope of their policy portfolios, the extent to which they delegate authority to independent bodies, the extent to which they pool authority in majoritarian decision-making, the frequency with which they are reformed - not normally distributed around their respective means? Does the apparently bimodal character of international organization have a general explanation?

To tackle this problem we need reasonably good comparative information about the institutional characteristics of IOs. The qualities we are interested in - policy scope, delegation, pooling, institutional reform - are abstract concepts that cannot be directly observed. We need therefore to make a series of conceptual and measurement decisions to produce data that can discipline the generalizations we wish to put on the table.

In the next section we conceptualize how international organizations exercise authority through independent non-state bodies (delegation) and through intergovernmental bodies that make collective decisions (pooling). We then model the composition of IO bodies and how they make decisions to estimate delegation and pooling in 72 IOs from 1950-2010. In subsequent sections we use this information to explain how the institutional structures of IOs vary cross-sectionally and over time.

\section{Delegation and Pooling}

We conceive of IO authority as two-sided. Member states can delegate authority to independent bodies - a general secretariat, independent executive, assembly, and court. And/or member states can pool authority among themselves in majoritarian or quasi-majoritarian procedures. Previous research finds that these two forms of IO authority are independent of each other (Hooghe/Marks 2014), and we need therefore to estimate them separately. The distinction between delegation and pooling is the 
bedrock of our measurement and our theory, but it is worth emphasizing that while the concepts have not been used to estimate or theorize international organizations, they are not new.

\section{Conceptualization}

The distinction between delegation and pooling first appeared in research on the European Community (EC). Keohane and Hoffmann (1991, p. 16 and p. 7) observe that the EC is an example of "supranationality without supranational institutions" because member states pool, but do not delegate, authority. Moravcsik (1993, p. 506) refers to the concepts "delegation and pooling" in tandem to encompass the authority exercised by the EC. Subsequent uses of the terms also employed them in combination to encompass the ways in which the European Union exercises authority (Hooghe/Marks 2001; Kohler-Koch/Rittberger 2007; Schimmelfennig et al. 2006). ${ }^{1}$

The assumption that they are closely related was explicitly questioned by Lake (2007, p. 220). Lake did not seek to assess the conditions under which pooling or delegation take place, but explained that they are conceptually distinct because they involve contrasting strategic imperatives. Whereas the strategic problem in delegating authority to an independent body is shirking in which the agent pursues its own agenda, the strategic problem in pooling authority is that of collective decisionmaking where a member state may be outvoted under majoritarian decision rules. However, as Lake notes, the distinction is by-passed in analyses which extend the concept of delegation to include pooling or which view international organization through the lens of the principal-agent perspective. The upshot is that our understanding of the contrasting logics of delegation and pooling is embryonic.

\section{Estimation}

In order to estimate the delegation and pooling of formal authority in international organizations, we need to pay detailed attention to actors making decisions under rules. ${ }^{2}$ With respect to the actors, we wish to know the extent to which the bodies that shape the agenda and make decisions are controlled by states. Pooling is the domain of interstate bodies - bodies entirely or primarily composed of member state representatives. Delegation is the domain of non-state bodies - general secretariats, consultative bodies, assemblies, executives, judicial bodies. With respect to rules, we wish to know how the interaction of voting rules and decision-making bodies empower or constrain states

1 The distinction is implied in the legalization (Abbott et al. 2000) and rational design projects (Koremenos et al. 2001). Abbott and Snidal (1998, p. 8f) use the concept of centralization to refer to "a concrete and stable organizational structure and a supportive administrative apparatus" while independence refers to "the authority to act with a degree of autonomy, and often with neutrality, in defined spheres." These attributes have an affinity with our concept of delegation. Koremenos et al. (2001) identify five elements of institutional design: membership rules, scope of issues, flexibility, centralization of tasks, and rules for controlling the institution. The final two overlap with delegation and pooling. Centralization refers to activities "to disseminate information, to reduce bargaining and transaction costs, and to enhance enforcement ... The least intrusive form of centralization is information collection" (pp. 771-2). Control "focus[es] on voting arrangements as one important and observable aspect of control" (p. 772). Recently, several researchers have begun to operationalize delegation, autonomy, or independence of international organizations (Conceiçao-Heldt 2013; Ege and Bauer 2013; Gehring 2013).

We investigate the formal rules and then determine whether these are translated into institutions in order to narrow the gap in coding between unrealized intention and actual practice (Gray and Slapin 2012; Haftel 2013). However, we do not code practices that have only an informal basis. The studies closest to ours are Blake and Lockwood Payton (2014), who estimate pooling by examining the voting rule in the IO body that they judge to be the most consequential in setting policy, Haftel and Thompson (2006), who propose a four-item additive index of IO independence in regional organizations that includes voting in the council of ministers (an element of pooling) and right of initiative by the bureaucracy (an element of delegation), and Goertz and Powers $(2011,2012)$ who map basic features of the institutional structure of "regional economic institutions" along five dimensions. Each of these studies has produced a dataset on the institutional design of IOs. We extend their efforts by encompassing a wide range of IOs over a 60 -year period, and by developing a multi-faceted measurement instrument that estimates both the extent to which IO bodies are independent and their decision-making across a range of fields. 
individually and collectively. Unanimity decision-making imposes no constraints on individual states, but hampers collective decision-making. Majoritarianism, in contrast, constrains states individually because they lose their ability to veto undesired decisions, but it facilitates collective decision-making. With respect to decisions, we wish to know the depth of obligation - how binding they are for states and whether they require ratification. We examine actors, rules, and decisions in six substantive fields: membership accession, membership suspension or expulsion, policy making, drafting the budget, budgetary non-compliance, and constitutional reform. Finally, we evaluate third-party dispute settlement in a separate analysis. We apply this schema to 72 IOs with standing in world politics from 1950 and 2010 (listed in Appendix I). ${ }^{3}$

We conceive of delegation as a transfer of authority from member states to a non-state IO body. Institutionally, this is most often to a general secretariat. However, member states can also cede control to other bodies that are partially or fully composed of non-governmental actors, such as transnational actors, elected public officials, experts, or judges. Our measure considers each of these possibilities. However, it excludes transfer of authority to bodies outside the IO, such as other international organizations or non-member national states.

Delegation is an additive index encompassing agenda setting, decision-making, and dispute settlement for each year of an IO's existence. It is the grant of authority by member states to a) organized bodies (general secretariat, consultative bodies, assemblies, executives, judicial bodies) b) that are non-state ${ }^{4}$ and c) play a role in agenda setting or final decision-making in d) one or several of the six decision areas listed above. The extent of delegation is a function of the number of non-state bodies and the number of decision areas in which they play a formal role. In dispute settlement, which we examine separately, delegation is a function of the extent to which third-party judicial bodies are independent of member state control, render binding rulings, and non-state actors have access to the body. We estimate each element separately, standardize, and sum in an additive index.

Pooling is an additive index tapping the extent to which authority is transferred from individual member states to a collective member state body in agenda setting and decision-making for each year of an IO's existence. Three elements are included in our assessment of the extent to which member states pool authority: first, whether the decision rule departs from unanimity to some form of majoritarianism; second, whether the decision is binding rather than voluntary; third, whether the decision comes into force without requiring ratification by individual member states. We estimate the extent to which member states pool authority by assessing voting rules, bindingness, and ratification in the same six domains listed above. The weakest link (i.e. the most intergovernmental option) prevails in each decision domain. So if two or more member state bodies are involved in a decision, we

The population consists of international governmental organizations that fulfill a minimum of five of the following six criteria:

- $\quad$ three or more member states

- a formal constitution or convention

- a legislative body, executive, and administration

- a permanent staff of 50 or more

- $\quad$ at least one annual meeting of the executive or legislature

- $\quad$ address and website.

We see two reasons for limiting the sample to IOs that have standing in international politics. The first is practical. Our theory requires us to evaluate IOs using much more information than available in any prior dataset, and given time and financial constraints it makes sense to estimate IOs that have a more detectable footprint in the primary and secondary records. Hence our decision to exclude IOs that have no website, address, or are poorly staffed. Second, while we think our theory might apply very broadly, we suspect that states may be more likely to pay attention to IOs that have some minimal level of resources.

4 A body is non-state when a) the members are primarily or wholly selected by national parliaments, regional or local governments, trade unions or business associations, or other interest groups, or b) member state representation is indirect, that is, representatives are formally prohibited from receiving voting instructions from their government, or they take an oath of independence. 
consider the rules that govern the most intergovernmental body. The maximum score is majority voting over a binding decision without ratification. The minimum score is unanimous decisionmaking, followed by nonbinding decision-making under supermajority, followed by ratification by all member states under supermajority. Supermajoritarian decision rules, partial ratification, and partial bindingness produce intermediate scores. Scores for each domain - agenda setting and final decision are treated as elements of a summated rating scale. ${ }^{5}$

\section{Patterns of International Organization}

We argue that the tension between community and scale shapes incentives over the basic form of cooperation and this is reflected in the size of an IO's membership, its decision rules, its institutional architecture and evolution, and the authority delegated to non-state bodies.

General purpose and task specific IOs are distinguished, above all, by the breadth of their policy portfolios. We estimate this by examining IO involvement in 25 policy areas listed in Appendix II. As Figure 1 illustrates, the distribution is bimodal. Twenty-eight IOs in our sample handle eleven or more policies on this list, and 44 handle eight or fewer policies. The median general purpose IO handles 15 policies and the median task specific IO handles three. These numbers can be considered upper bounds because our measure is designed to be sensitive; it detects five distinct forms of IO policy involvement and does so for a refined set of policies.

5 The two dimensions of authority - pooling and delegation - are weakly correlated (0.06). The coding scheme was honed over iterated rounds of independent coding by two graduate-faculty teams using a subset of organizations. The final coding scheme was applied by six researchers, two of whom had guided the project from day one. Coding decisions are set out and documented in profiles (around 4,500 words for each IO). The full coding scheme is available here: http://www.falw.vu/ mlg/igo.html. 


\section{Figure 1: Policy scope for general purpose and task specific organizations ${ }^{6}$}

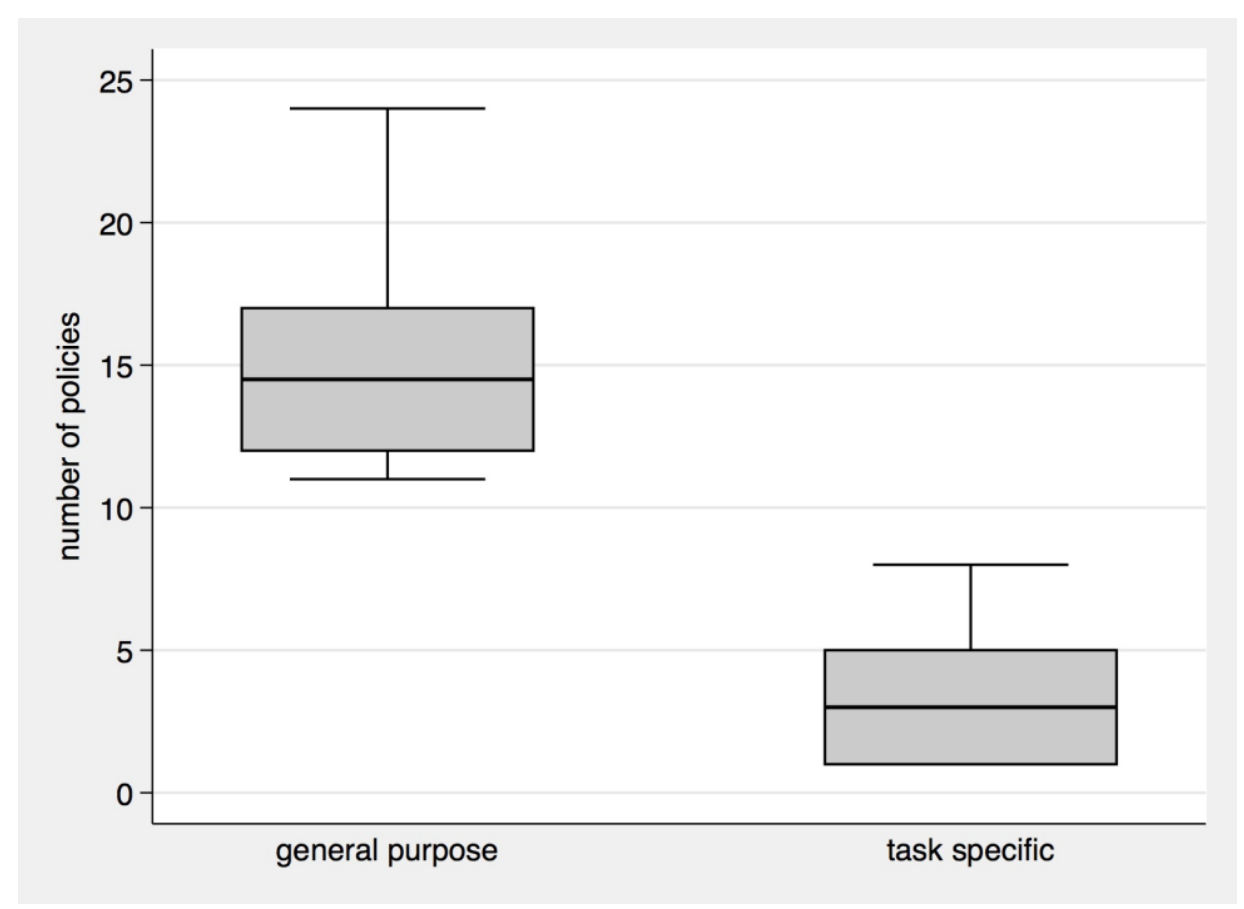

Note: $N=72$ for 2010. Policy scope is estimated on a 1-25 scale (Appendix II).

General purpose and task specific IOs relate to their constituencies differently, and this shapes the scale of their membership. General purpose IOs handle the problems that confront a given set of peoples as they interact across national borders. Consequently, they are formed by states whose peoples have some mutuality of expectations underpinning a shared sense of purpose. They require what Elinor Ostrom (2005) describes as "shared mental maps" - a bed of common understandings that facilitate convergent interpretation of behavior. This eases open-ended cooperation based on highly incomplete contracts, which require not only that other members believe one's promises but also that they understand one's promises (Gibbons and Henderson 2012, p. 1351). Almost all general purpose IOs are composed of contiguous member states. ${ }^{7}$ The exceptions are illuminating. The Organization of the Islamic Conference unites countries in North Africa, the Arab world, and East Asia, where Islam provides a shared sense of purpose. The Commonwealth encompasses countries that were formerly part of the British imperial orbit, and the United Nations is the only IO that is involved in more than eleven policies but which has a frail community basis.

Task specific organizations are less restrictive over membership but more restrictive over policy. They handle policies that can be isolated from the pack and which are amenable to technical solutions. Task specific IOs are problem driven, and this relieves them from the community conditions required for general purpose governance. Their forte is encompassing all those who are affected by a problem. Hence task specific governance is predominant in dealing with problems that have global externalities and a correspondingly weak community basis. The only large-member organization in Figure 2 that is not task specific is the United Nations. However, task specific IOs are not necessarily global. Some task specific IOs handle regional problems that are amenable to independent management. For

6 The data contained in this article are presented in more extensive form in Gary Marks, Liesbet Hooghe, Tobias Lenz, Jeanine Bezuijen, Besir Ceka, and Svet Derderyan. 2015. Scale and Community. The Design of International Organizations. Oxford: Oxford University Press.

7 Or adjacent island states in, for example, the Pacific Islands Forum and the South Pacific Commission. 
example, the Central Commission for the Navigation of the Rhine (CCNR) regulates social rights and environmental externalities related to shipping on the Rhine. The Organization of PetroleumExporting Countries (OPEC) coordinates production and price setting among oil-exporting economies. The Intergovernmental Organization for International Carriage by Rail (OTIF) sets standards for railways in Europe and contiguous countries in Central Asia and the Middle East. In our theory, these organizations share more with other task specific IOs than with other IOs that can be labelled "regional."

Figure 2: Size of membership in general purpose and task specific organizations

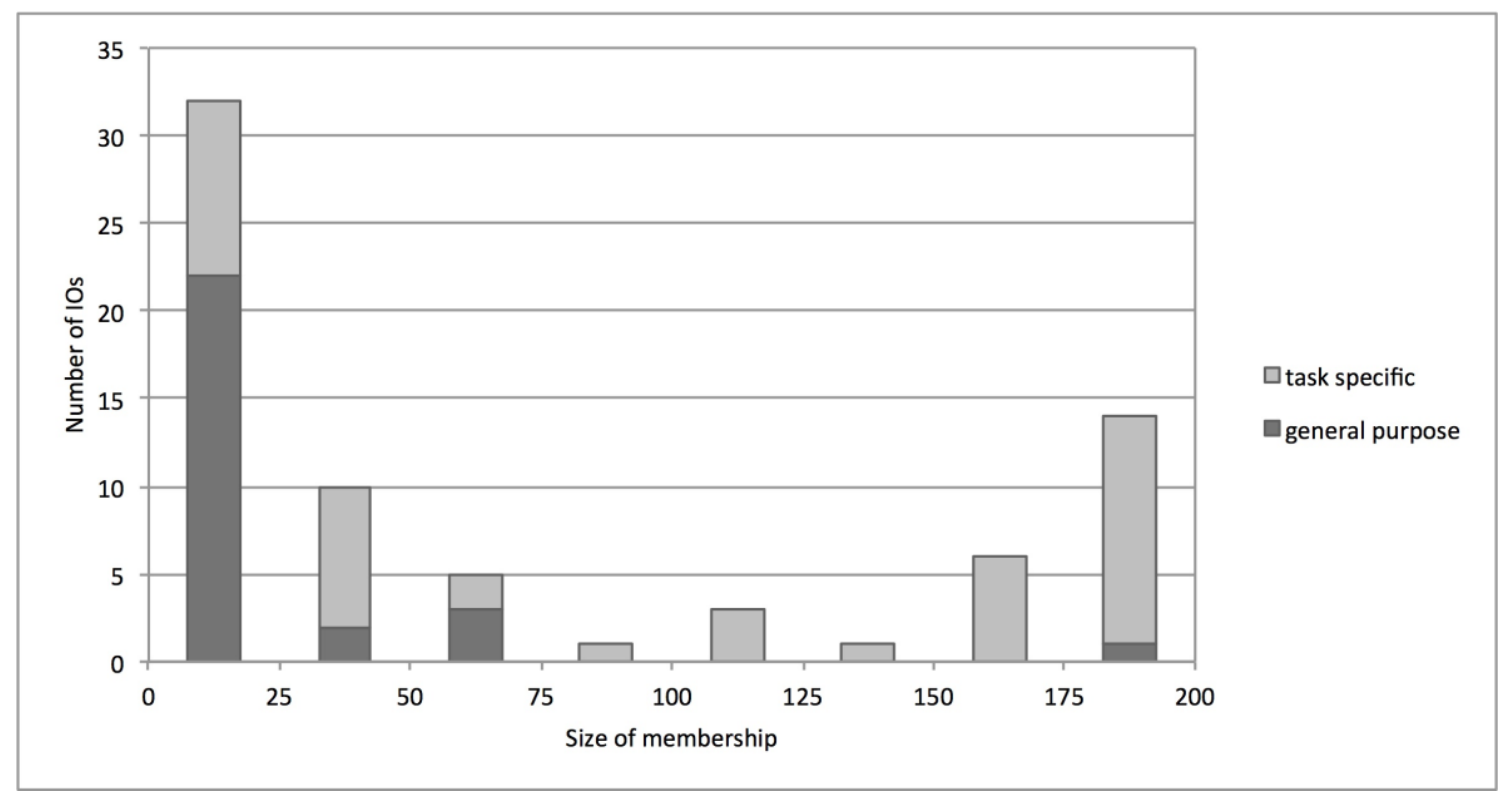

Note: $N=72$, year=2010. Source: $C O W$ (with minor corrections).

\section{Contrasts in pooling}

Pooling of authority is primarily a property of task specific IOs. Figure 3a breaks down the incidence of majoritarian decision-making across six policy areas for task specific and general purpose IOs for 2010. Fifty-five percent of the task specific IOs have pooling in five or six policy areas against just eleven percent of general purpose IOs. 
Figure 3a: Pooling across policy areas in 2010. $\mathrm{N}=72$.

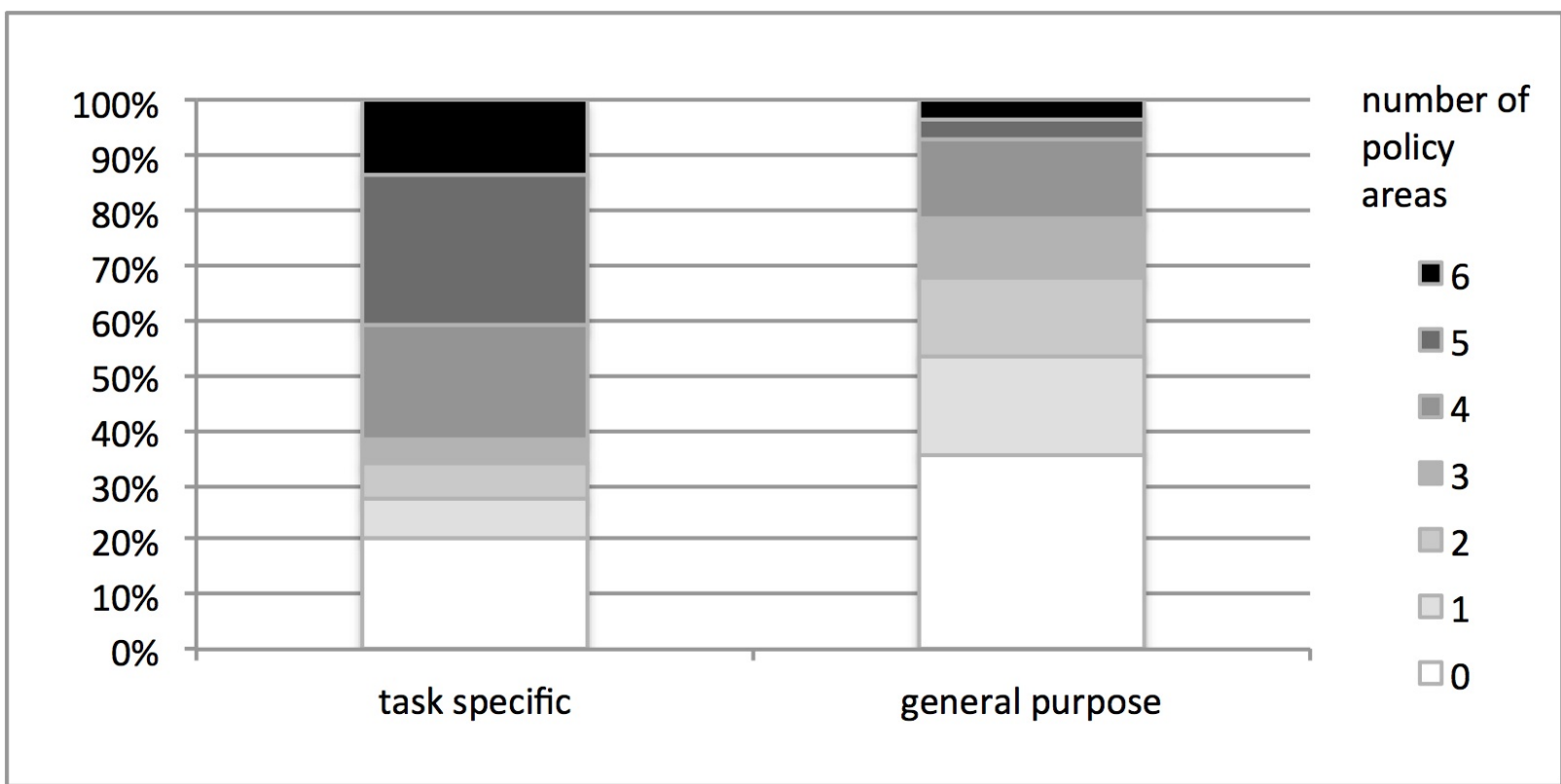

Note: Darker colors reflect the number of policy areas from a maximum of six (membership accession, membership suspension, policy making, drafting the budget, budgetary non-compliance, constitutional reform) in which an IO pools authority.

This contrast persists over time. Figure $3 \mathrm{~b}$ shows the trends in pooling for the 18 general purpose and 33 task specific IOs that have existed since 1975. Pooling edges up slightly for general purpose IOs after 2000, but the gap remains substantial.

Two factors combine to limit the pooling of authority in general purpose IOs and increase it in task specific IOs. The first arises because general purpose IOs are far more likely to engage issues of domestic concern to national governments, and this makes the member states much less willing to sacrifice the national veto (Hooghe/Marks 2009b; Zürn et al. 2012; see also Rixen/Zangl 2012). IOs like to portray themselves as "being impersonal and neutral, that is, that they are not exercising power but instead are using impartial, objective, and value-neutral knowledge to serve others" (Barnett/Coleman 2005, p. 598). This becomes more difficult as IO decisions reach into member states. The cloak of technocratic detachment fades when an IO allocates scarce resources across competing domestic interests. Most member state governments have legitimacy over issues considered to be matters of diplomacy, but this does not extend to international agreements that have domestic repercussions. It is all too easy for populists to frame the domestic debate over a controversial IO decision as the defense of national sovereignty against foreign interference (Hooghe/Marks 2009b). ${ }^{8}$ No wonder that national governments are intent on maintaining the national veto in IOs that are perceived to affect their domestic support.

8 Task specific IOs sometimes take decisions that cause domestic disquiet and even revolt - e.g. the IMF in Argentina, Mexico, or Thailand; the IAEA in Iran or North Korea - but these effects are felt in states that are the object of IO decision-making, rather than the member states that decide the policy. 
Figure 3b: Trends in pooling $1975-2010 . \quad \mathrm{N}=51$.

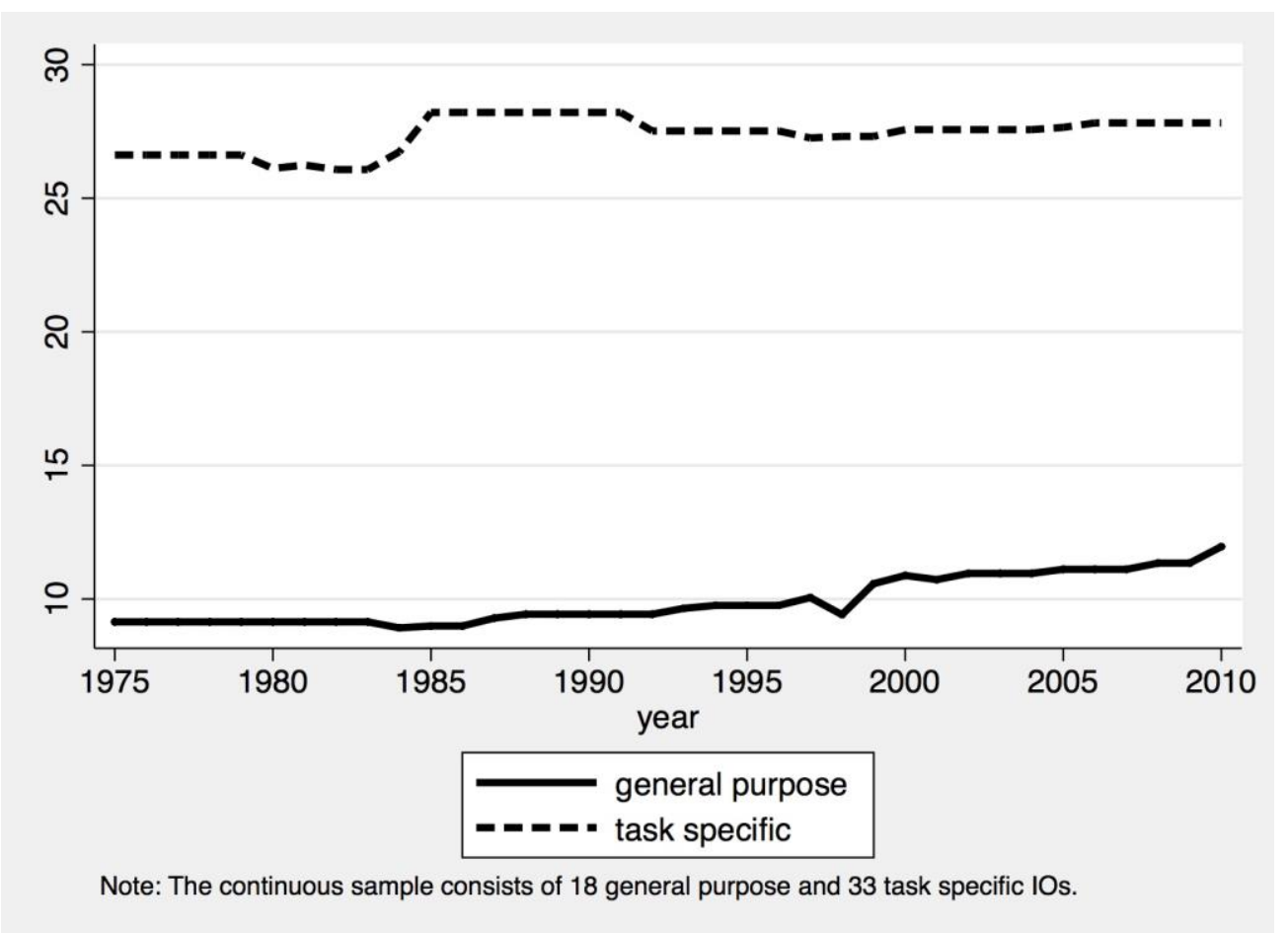

Historically, task specific IOs have been at the forefront of pooling authority in majoritarian decisions. Stephen Zamora, a historian of international organization, stresses that supranational decision-making was most palatable in IOs that dealt with specialized issues which did not much impinge on domestic policy. The first departures from unanimity voting were introduced in the international technical unions established during the 19th and early 20th centuries, the first being the International Telegraphic Union (ITU) in 1865, which was then the largest international organization with 15 members. By 1914, several organizations, including the Universal Postal Union with 33 members and the International Institute of Agriculture (forerunner of the Food and Agricultural Organization) with 37 members, had introduced majority voting. After the First World War, majority rule spread slowly to other new technical unions (Zamora 1980, pp. 574-5).

The second factor that affects the willingness of member states to pool authority arises from the size of its membership. All else equal, the larger the number of veto-wielding decision makers, the more difficult it is to craft reform. Task specific IOs face the dilemma that their sheer scale of membership will reduce them to talking shops incapable of action. Streamlining decision-making by relaxing the national veto is an obvious response. Majoritarian procedures are made more palatable for member states when the contract on which the organization is based expressly limits its policy reach or when the organization is biased towards technocratic problem solving.

The two logics of pooling can create huge tensions in a general purpose organization that grows in membership. The European Union is a case in point. National governments have been caught in a stressful choice between facilitating decision-making and holding on to the national veto. When majoritarian procedures have been adopted, this has only been because it appeared to be the least-bad response to membership enlargement. The 1985 Dooge committee, which was tasked with making proposals for the Single European Act, noted that "more use will need to be made, especially in the context of the enlarged Community, of the majority voting provisions laid down in the Treaties" (Dooge Committee 1985, p. 14). British Prime Minister Margaret Thatcher and her allies succeeded initially in limiting majority voting to the internal market, but efficiency became an overriding concern 
in planning for Eastern enlargement. In December 2001, the Laeken Declaration of the European Council launched a Constitutional Convention to overhaul the institutions. It stated bluntly that a

"key question concerns how we can improve the efficiency of decision-making and the workings of the institutions in a Union of some thirty Member States. How could the Union set its objectives and priorities more effectively and ensure better implementation? Is there a need for more decisions by a qualified majority? How is the co-decision procedure between the Council and the European Parliament to be simplified and speeded up?" (European Council 2001, p. 5)

The outcome was a highly contested redesign of decision-making that involved lowering the threshold for qualified majority voting. ${ }^{9}$

However, it would be misleading to see the EU as indicative of a general trend among general purpose IOs towards majoritarianism. The EU is an outlier among general purpose IOs both in terms of the extent of its enlargement, from six to 28 (and counting), and in terms of the extent to which it has agreed to majoritarian reform. It is no coincidence that the EU is also an outlier in terms of the domestic political resistance that it has generated.

\section{Institutional architecture}

General purpose and task specific IOs differ in their institutional architecture. Almost all IOs have a general secretariat with administrative functions, but general purpose organizations tend to have a greater range of decision-making assemblies and executive bodies. As Figure 4 indicates, the median general purpose organization has four integral bodies compared to three for the median task specific organization. ${ }^{10}$ The general purpose organization with the most differentiated institutional architecture - the European Union - has seven different bodies. Among the IOs we observe, the League of Arab States is the only general purpose organization with only two bodies, whereas there are six task specific organizations with just two bodies. ${ }^{11}$

9 This is not to deny that consensus remains the dominant informal decision rule in the EU. Nevertheless, changes in formal rules towards majoritarian decision-making condition bargaining dynamics, especially over controversial issues, as they shift the burden of justification towards the state that seeks to veto. Whereas formal unanimity grants each state a veto that does not require justification, majoritarian decision-making implies that recalcitrant states must convince the others to apply the informal consensus rule (on informal IOs, see Vabulas and Snidal 2013).

10 Some IOs are supported by a tiered administrative structure, whereby assemblies, executives, or the general secretariat are aided by subsidiary committees or groups that prepare decisions, follow up on implementation, or study particular aspects. We code only those bodies with some discretion within the IO structure - not auxiliary bodies in a chain of command to a higher body.

11

The Council of the League of Arab States serves as assembly and executive and is assisted by a general secretariat. Among task specific IOs, the European Organization for Nuclear Research and the European Space Agency have an assembly and a secretariat, which also serves as executive. The Central Commission on the Navigation of the Rhine, the Permanent Court of Arbitration, the International Whaling Commission, and the European Free Trade Association have councils which double as assemblies and executives. 
Figure 4: Institutional complexity in 2010

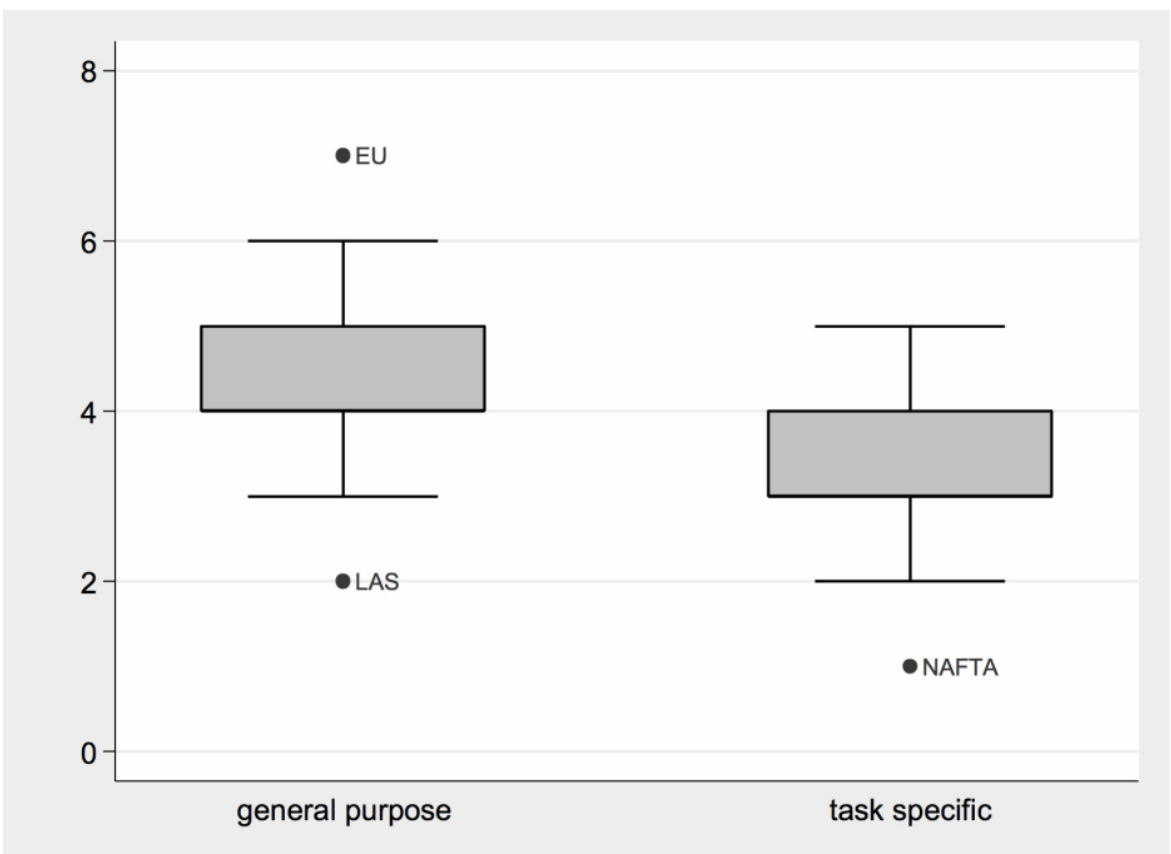

Note: Institutional complexity is estimated as the number of decision making bodies in general purpose and task specific organizations in 2010. $N=72$.

The contrast reflects the differing scope of policy competences in general purpose and task specific IOs. More diverse policy portfolios may require more differentiated institutional structures. Decisionmaking in a general purpose IO is particularly challenging. The organization must frame short and medium term objectives, and agree on how best to pursue them. It must prevent issue cycling among alternative legislative proposals - a particular danger in the multidimensional issue spaces typical of general purpose organizations. It must determine which actors to consult in crafting policies and must negotiate substantive commitments. And it must find ways to promote compliance with those commitments. Institutions can help in each of these respects by structuring the agenda, supplying and processing information, enhancing the credibility of commitments, and monitoring compliance (Bradley/Kelley 2008; Hawkins et al. 2006; Koremenos 2007, 2008; Pollack 2003).

Beyond this, institutions can reduce the uncertainty of incomplete contracting, which is particularly pronounced in general purpose IOs. Whereas task specific IOs take on problems that can be quite well specified in advance, general purpose IOs operate in a more open-textured environment for they are concerned with the problems that arise as peoples interact across national borders. General purpose IOs are correspondingly based on highly incomplete contracts that are flexible in responding to contingencies that are inherently unpredictable, complicated and consequently too costly to write into a contract. Their virtue is flexibility, but this involves ambiguity about the interpretation of rules and it deepens the shadow of the future (Hart/Moore 2008; Marks et al. 2014). Independent arbitration panels or courts are especially important when there is so much room for disagreement about what counts as cooperation and defection. Greater uncertainty about the rules may produce incentives for greater institutional complexity beyond rule arbitration. If highly incomplete contracting involves not merely rule-based problem solving, but searching and learning, then one may expect institutions to play a critical role in discovering as well as realizing cooperation.

General purpose IOs delegate much more extensively to non-state bodies composed of elected parliamentarians as Figure 5 reveals (Cutler 2013; Tallberg et al. 2015). Fifteen of 28 general purpose IOs have a parliament compared to five of 44 task specific IOs. Parliamentary bodies are the third most prevalent delegated institution among general purpose IOs but the least common among task 
specific organizations. Moreover, parliaments in general purpose IOs tend to be more authoritative than those in task specific IOs. The strongest of all, the European Parliament, co-decides on accession, budgetary allocation, and policy making, and it has additional agenda-setting powers on suspension and constitutional amendment. The rise of parliaments, like that of independent IO bodies in general, has been marked since the 1980s. The only IO in our dataset with a parliamentary body in 1950 was the North Atlantic Treaty Organization. By 1980, seven IOs had parliaments, rising to 22 by 2010.

The relative paucity of parliamentary bodies in task specific IOs and their abundance in general purpose IOs reflects the contrasting ways in which these types of governance seek legitimacy (Lenz 2012, 2013; see also the contributions in section II). Task specific IOs are in the business of managing particular coordination or collaboration dilemmas (Snidal 1985; Zürn 1992). They are oriented chiefly to Pareto optimality and are biased towards output legitimacy in which they are evaluated primarily by results. To the limited extent that parliamentary bodies in task specific IOs are created at all, they have consultative competences only. General purpose organizations, by contrast, engage redistributive as well as technical policies, and they have a correspondingly greater need to legitimate their decisions. Granting elected national parliamentarians access to supranational decision-making is one way to do this.

Figure 5: Presence and role of parliaments in 2010. $N=72$.

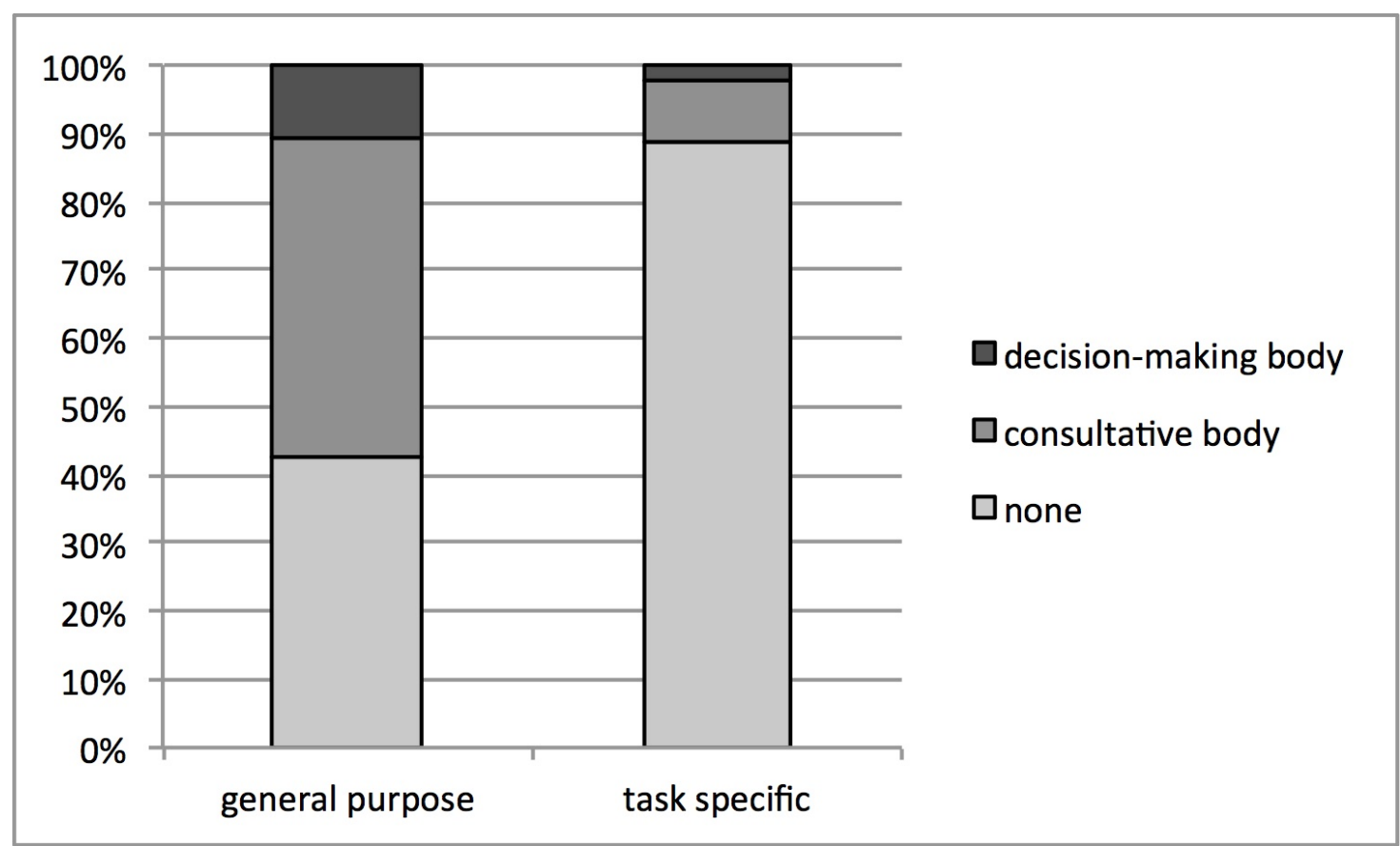

Note: Bars indicate the proportion of IOs with a decision-making parliament, a consultative parliament, or no parliament. Fifteen of 28 general purpose IOs have a decision making or consultative parliament compared to five of 44 task specific IOs.

\section{Delegation dynamics}

The contrast between general purpose and task specific IOs extends to how they change over time. Whereas task specific IOs are designed to fulfill a particular function, general purpose IOs are designed to solve problems that confront a given community. General purpose IOs have a broader and less precise purpose that leads to greater institutional flexibility. The development of general purpose IOs resembles state building in its lack of a master plan - a founding constitution specifying, once and for all, the scope and responsibilities of the organization, its institutional make-up, the level of resource extraction, or its relations with state and non-state actors (Marks 1997). 
Both kinds of organization are based on formal contracts among states. All such contracts are necessarily incomplete because it is simply not possible to write a contract that can specify "the full array of responsibilities and obligations of the contracting parties, as well as anticipate every possible future contingency" (Cooley/Spruyt 2009, p. 8). But the contracts that underpin general purpose IOs are considerably more incomplete than those that underpin task specific IOs. The treaties for task specific organizations have a clearly defined objective oriented to the management of a specific cooperation problem, such as lowering barriers to trade or coordinating the use of an international common pool resource, and they usually set out in some detail how this objective is to be achieved.

The founding agreements of general purpose organizations do little more than set out the broad parameters for cooperation. They commit their members to open-ended goals - for example, "ever closer Union" in the European Community's Treaty of Rome; the "formation of an Andean subregional community" in the Andean Community's 1974 Cartagena Agreement; or the "creation of a homogenous society" in the Economic Community of West African States' Lagos Treaty. The founding contracts of this type of organization emphasize the process rather than the destination of cooperation (Marks et al. 2014).

The implications should be understood in both functional and ideational terms. From a functional standpoint, agenda setting in general purpose IOs is unusually complex, and so it is particularly useful to set up independent bodies to fill in the details of incomplete contracts, generate expert policyrelevant information, and monitor compliance (Pollack 2003, p. 378; Bradley and Kelley 2008). A general secretariat with the authority to sequence votes can also limit the opportunities for states to defect from a winning coalition by making a more attractive offer centered on a different proposal (Tallberg 2010). This, in a nutshell, is the notion that incomplete contracting induces states to delegate authority to non-state actors to reduce uncertainty and limit issue-cycling (Hawkins et al. 2006; Marks et al. 2014; Mueller 2003; Pollack 2003).

Highly incomplete contracting in a general purpose organization has normative as well as policy effects along the lines highlighted by Chayes and Chayes (1993, p. 180):

"[M]odern treaty making, like legislation in a democratic polity, can be seen as a creative enterprise through which the parties not only weigh the benefits and burdens of commitment but explore, redefine, and sometimes discover their interests. It is at its best a learning process in which not only national positions but also conceptions of national interest evolve."

As cooperation progresses, IO decision makers may come to share frames of reference that reduce perceptual conflicts and ameliorate fear of exploitation (Acharya 2004; Katzenstein 2005; Wendt 1999). Barnett and Finnemore (2004, p. 23) find that the authority of international bureaucrats rests on "a contrary discourse of states protecting their own national and particularistic interests" and on representing "the community against self-seekers." Other studies find that IO bureaucrats spend most of their time bridging the distance between national norms and common solutions and that they are best conceived as mediators between national values and international norms. On the basis of a panel study of top administrators in the European Commission, Hooghe $(2005$, p. 862) finds that "top officials sustain international norms when national experiences motivate them to do so - when national political socialization predisposes them to embrace supranationalism, or when supranationalism appears to benefit their country." These studies find that delegated bodies have a dynamic effect in facilitating repeated interaction and developing a normative basis for cooperation (see also Koch 2009). 
Figure 6: Trends in delegation, $1975-2010 . \mathrm{N}=51$.

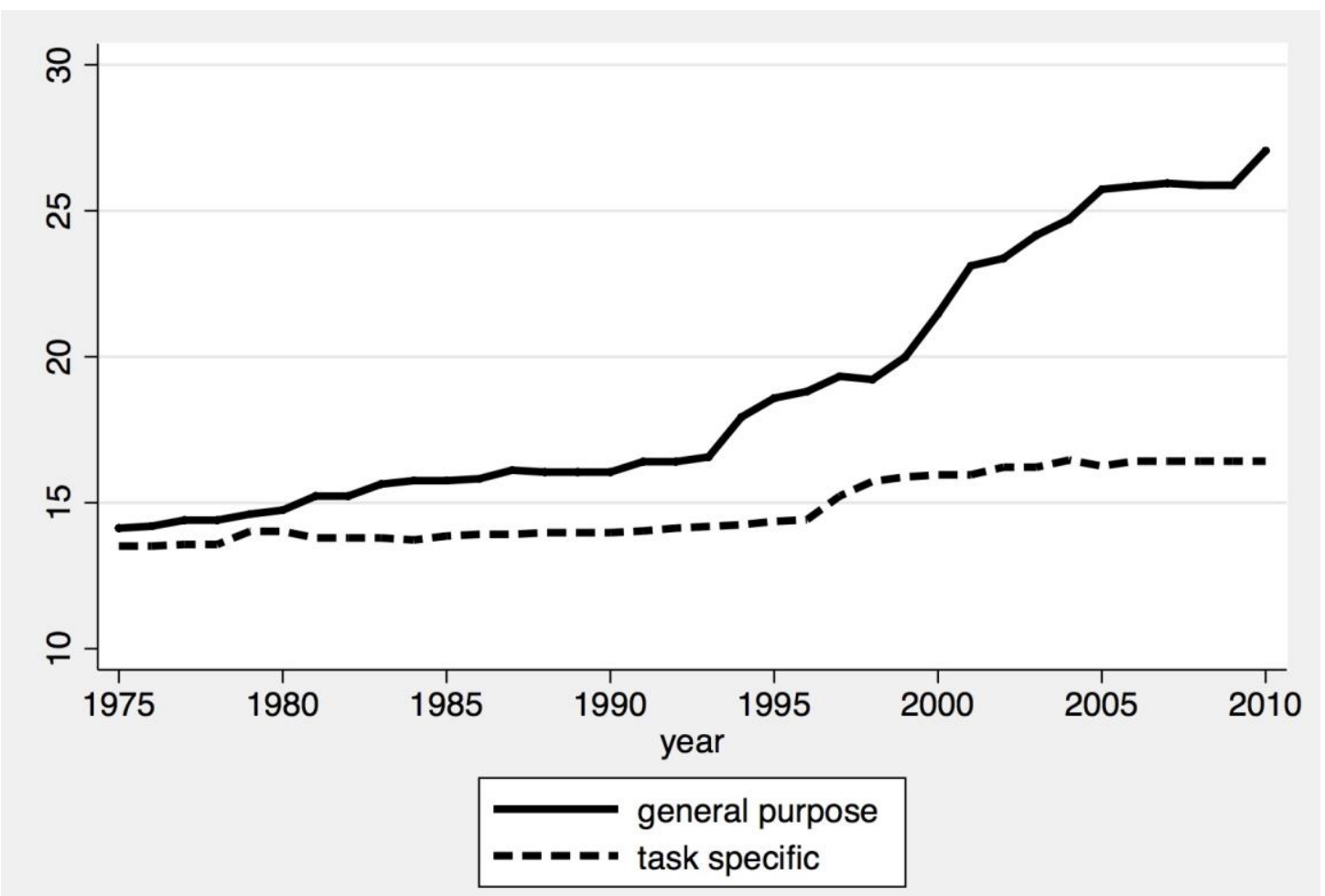

Note: The continuous sample consists of 18 general purpose and 33 task specific IOs.

In line with this, the information we have gathered indicates that the contrast between delegation in general purpose and task specific IOs gathers steam over time. In 1975, general purpose IOs have an average delegation score of 14.1, rising in 2010 to 27.1 for the same organizations. This is equivalent to establishing a standing tribunal with automatic right to review and binding decision-making, or to creating two additional consultative bodies and empowering a general secretariat to set the agenda in two additional decision areas. By contrast, the average task specific IO has barely budged over time.

The contrast extends to the frequency of reform. Figure 7 displays the distribution of reforms in the two types of organizations. We define an organizational reform as a change in any element of our pooling or delegation measure after the founding bargain has been struck. Forty-one percent of task specific IOs never undergo reform compared to just seven percent of general purpose IOs. Whereas general purpose organizations reform every 15 years on average, task specific ones reform only every 36 years. 
Figure 7: Distribution of reforms, 1950 - 2010.
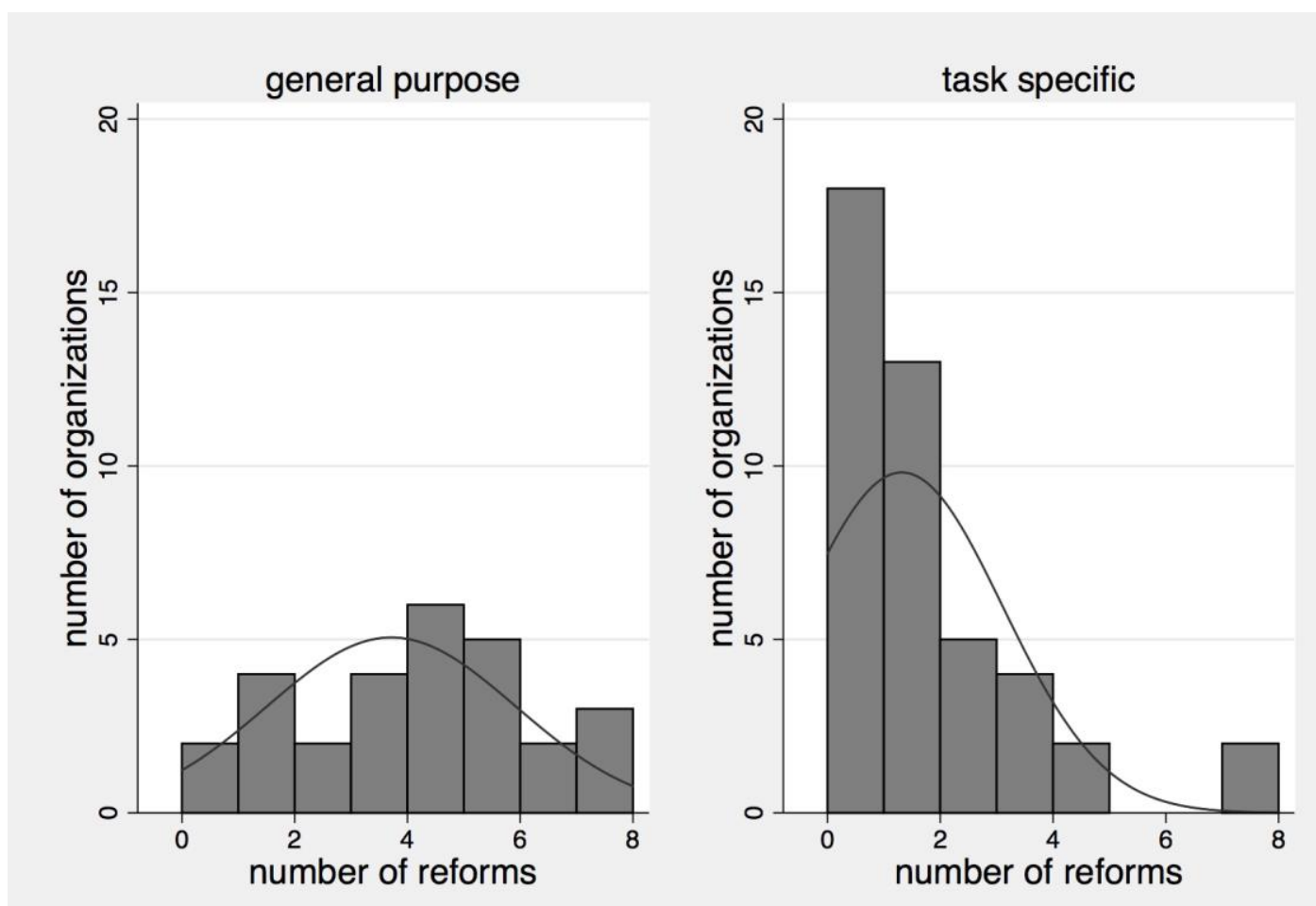

$\mathrm{N}=72$. Total number of years in which a reform takes place.

Note: The bars show the number of reforms for each IO since its foundation or since 1950 (whichever date is later). For example, just 2 general purpose IOs have seen no reform compared to 18 task specific IOs.

\section{Conclusion}

This paper surveys some basic features of international organization using a new dataset, constructed by the authors, that estimates 72 IOs from 1950 to 2010 . We theorize that the differences one can observe among international organizations in their institutional architecture, their decision-making, and their institutional trajectory result from the contrasting ways in which human beings confront the fundamental dilemma of international governance. There are enormous benefits arising from scale in the provision of public goods. Overarching jurisdictions are uniquely able to manage problems that stem from interaction among nations and their peoples. Yet the feeling of 'we-ness' that underpins good government is at best weak. But it is not always absent. The existence of even weak communities among nations makes possible general purpose international organization.

General purpose IOs express a sense of shared purpose among their members. They bundle competences for given sets of peoples who, by virtue of their interaction, share a demand for transnational public goods. The membership of general purpose IOs is territorially bounded, and enlargement is a serious matter requiring debate and consensus. Membership of such an IO involves commitments that can affect national sovereignty on a broad front, and their member states are generally unwilling to pool their authority in majoritarian decision-making. But general purpose IOs discover, as well as implement, cooperation. They are designed to negotiate complex issues, and despite the obstacles to reform, they are institutionally flexible.

Task specific governance is distinctly different. It is problem driven, and is intended to provide public goods for a diffusely defined membership that can cover the globe. The legitimacy of task specific IOs lies chiefly in their effectiveness in managing problems. They have a correspondingly 
limited capacity to facilitate distributional bargains, but are oriented to Pareto optimality in which every participant is at least no worse off than before. There tends to be less variety in their structure, less emphasis on including non-state actors, and less institutional change over time.

Abstract concepts that have been applied to international organizations are challenging to evaluate in empirical analysis. We conceive an IO as a web of rules and we analyze these rules with the help of two precisely formulated concepts which describe both the composition and decision-making of IO bodies. One dimension of variation arises when IO bodies have conditional independence over certain functions, which we conceptualize as delegation. Another arises to the extent that member states make collectively binding decisions under majoritarian rules, which we conceptualize as pooling. The distinction is mooted in the literature, but has remained theoretically inert. Here the distinction motivates both our measurement and theory.

While majoritarian decision-making is a functionally efficient approach to decision-making among states, it is predominant only in task specific organizations. The exception, the European Union, reveals just how difficult it is for states to institute majoritarian rules over decisions that are regarded as intrinsic to their national political life. Task specific IOs, which are functionally oriented to solving particular policy problems, confront the national veto with greater expediency. Pooling authority in budgetary allocation and ordinary policy making is very common among task specific IOs but much less widespread among general purpose IOs.

Conversely, general purpose IOs develop considerably higher levels of delegated authority than task specific IOs. General purpose IOs are designed to provide public goods on a broad, imprecise, front, and this is reflected in their institutional trajectories. Over time, general purpose IOs accumulate non-state bodies - strong general secretariats, indirectly or directly elected parliamentary assemblies with decision-making power, and consultative bodies of diverse kinds. It is worth noting that such institutional complexity is not given at birth, but develops in iterated reform. This suggests that general purpose IOs shape preferences as well as the means for realizing them. ${ }^{12}$

12 The importance of shared expectations for cooperation underpins a literature that builds on Habermas' (1981) conception of a "common lifeworld" (gemeinsame Lebenswelt), a supply of collective interpretations of the world provided by a common history or culture "to which actors can refer in their communications" (Risse 2000, p. 14). 


\section{References}

Abbott, Kenneth W., Robert O. Keohane, Andrew Moravcsik, Anne-Marie Slaughter, and Duncan Snidal. 2000. The Concept of Legalization. International Organization 54:401-419.

Abbott, Kenneth W., and Duncan Snidal. 1998. Why States Act Through Formal International Organizations. International Organization 42:3-32.

Acharya, Amitav. 2004. How Ideas Spread. Whose Norms Matter? Norm Localization and Institutional Change in Asian Regionalism. International Organization 58:239-275.

Barnett, Michael, and Martha Finnemore. 2004. Rules for the World. Ithaca, N.Y.: Cornell University Press.

Barnett, Michael, and Liv Coleman. 2005. Designing Police. Interpol and the Study of Change in International Organizations. International Studies Quarterly 49:593-619.

Blake, Daniel, and Autumn Lockwood Payton. 2014. Balancing Design Objectives. Analyzing New Data on Voting Rules in Intergovernmental Organizations. Review of International Organizations (forthcoming).

Bradley, Curtis A., and Judith G. Kelley. 2008. The Concept of International Delegation. Law and Contemporary Problems 71:1-36.

Chayes, Abram, and Antonia Handler Chayes. 1993. On Compliance. International Organization 47:175-205.

Conceição-Heldt, Eugenia. 2013. Delegation of Power to International Organizations and Institutional Empowerment over Time. Paper presented at the ECPR Joint Sessions, 11-16 March, Mainz.

Cooley, Alexander, and Hendrik Spruyt. 2009. Contracting States. Sovereign Transfers in International Relations. Princeton: Princeton University Press.

Cutler, Robert. 2013. International Parliamentary Institutions as Organizations. Journal of International Organizations Studies 4:104-126.

Deutsch, Karl W. [1953] 1966. Nationalism and Social Communication. An Inquiry into the Foundations of Nationality. Cambridge, M.A.: MIT Press.

Dooge committee. 1985. Report from the ad hoc Committee on Institutional Affairs. Bulletin of the European Communities, No 3. Luxembourg: Office for official publications of the European Communities, p. 14 (downloaded from www.cvce.eu.).

Ege, Jörg, and Michael Bauer. 2013. International Bureaucracies from a Public Administration and International Relations Perspective. In Routledge Handbook of International Organization, Ed. Bob Reinalda, 135-148. London: Routledge.

Enderlein, Hendrik, Sonja Wälti, and Michael Zürn (Eds.). 2010. Handbook on Multi-Level Governance. Cheltenham/Northhampton, M.A.: Edward Elgar.

European Council. 2001. Laeken Declaration of 15 December 2001 on the Future of the European Union. Bulletin of the European Union, No 12. Luxembourg: Office for Official Publications of the European Communities, p. 5 (downloaded from www.cvce.eu.).

Gehring, Thomas. 2009. Internationale Organisationen als Organisationen. Was die Organisationsforschung von der Systemtheorie lernen kann. In Die Organisierte Welt. Internationale Beziehungen und Organisationsforschung, Eds. Klaus Dingwerth, Dieter Kerwer, and Andreas Nölke, 59-94. Baden-Baden: Nomos. 
Gibbons, Robert, and Rebecca Henderson. 2012. Relational Contracts and Organizational Capabilities. Organization Science 23:1350-1064.

Goertz, Gary, and Kathy Powers. 2012. Regional Governance. The Evolution of A New Institutional Form. Paper presented at a workshop on An International Organization Database, 23-24 February, Wissenschaftszentrum Berlin.

Gray, Julia, and Jonathan Slapin. 2012. How Effective are Preferential Trade Agreements? Ask the Experts. Review of International Organizations 7:309-333.

Habermas, Jürgen. 1981. Theorie des kommunikativen Handelns. 2 vols. Frankfurt am Main: Suhrkamp.

Haftel, Yoram Z. 2013. Commerce and Institutions. Trade, Scope, and the Design of Regional Economic Organizations. Review of International Organizations 8:389-414.

Haftel, Yoram Z., and Alexander Thompson. 2006. The Independence of International Organizations. Concept and Applications. Journal of Conflict Resolution 50:253-275.

Hart, Oliver, and John Moore. 2008. Contracts as Reference Points. The Quarterly Journal of Economics 123:1-48.

Hasenclever, Andreas, Peter Mayer, and Volker Rittberger. 1997. Theories of International Regimes. Cambridge: Cambridge University Press.

Hawkins, Darren G., David A. Lake, Daniel L. Nielson, and Michael J. Tierney (Eds.). 2006. Delegation and Agency in International Organizations. Cambridge, M.A.: Cambridge University Press.

Hooghe, Liesbet. 2005. Many Roads Lead To International Norms, But Few Via International Socialization. A Case Study of the European Commission. International Organization 59:861-898.

Hooghe, Liesbet, and Gary Marks. 2001. Multi-Level Governance and European Integration. Lanham: Rowman and Littlefield.

Hooghe, Liesbet, and Gary Marks. 2003. Unravelling the Central State, But How? Types of MultiLevel Governance. American Political Science Review 97:233-243.

Hooghe, Liesbet, and Gary Marks. 2009a. Efficiency and the Territorial Structure of Government. Annual Review of Political Science 12:225-241.

Hooghe, Liesbet, and Gary Marks. 2009b. A Postfunctionalist Theory of European Integration. From Permissive Consensus to Constraining Dissensus. British Journal of Political Science 39:1-23.

Hooghe, Liesbet, and Gary Marks. 2010. Types of Multi-Level Governance. In Handbook on MultiLevel Governance, Eds. Hendrik Enderlein, Sonja Wälti, and Michael Zürn, 17-31. Cheltenham/Northhampton, M.A.: Edward Elgar.

Hooghe, Liesbet, and Gary Marks. 2014. Delegation and Pooling in International Governmental Organizations. Review of International Organizations (forthcoming).

Katzenstein, Peter. 2005. A World of Regions. Asia and Europe in the American Imperium. Ithaca, N.Y.: Cornell University Press.

Keohane, Robert, and Stanley Hoffmann. 1991. Institutional Change in Europe in the 1980s. In dies.: The New European Community. Decisionmaking and Institutional Change, 1-40. Boulder, C.O.: Westview Press.

Koch, Martin. 2009. Autonomization of IGOs. International Political Sociology 3:431-448.

Kohler-Koch, Beate, and Berthold Rittberger (Eds.). 2007. Debating the Democratic Legitimacy of the European Union. Lanham: Rowman \& Littlefield. 
Koremenos, Barbara. 2007. If Only Half of International Agreements Have Dispute Resolution Provisions, Which Half Needs Explaining? Journal of Legal Studies 36:189-212.

Koremenos, Barbara. 2008. When, What and Why Do States Choose to Delegate? Law and Contemporary Problems 71:151-192.

Koremenos, Barbara, Charles Lipson, and Duncan Snidal. 2001. The Rational Design of International Institutions. International Organization 55:761-799.

Lake, David A. 2007. Delegating Divisible Sovereignty. Sweeping a Conceptual Minefield. Review of International Organizations 2:219-237.

Lenz, Tobias. 2012. Spurred Emulation. The EU and Regional Integration in Mercosur and SADC. West European Politics 35:155-174.

Lenz, Tobias. 2013. The Politics of Institutional Symbolism. Parliamentarization in Regional Economic Organizations. Paper presented at the conference 'The Legitimation and Delegitimation of Global Governance Organizations', 11-13 September, University of Bremen.

Lindberg, Leon N., and Stuart A. Scheingold. 1970. Europe's Would-Be Polity. Patterns of Change in the European Community. Englewood Cliffs, NJ: Prentice Hall.

Marks, Gary. 1997. A Third Lens. Comparing European Integration and State Building. In European Integration in Social and Historical Perspective. 1850 to the Present, Eds. Jytte Klausen, and Louise A. Tilly, 23-50. New York: Rowman and Littlefield.

Marks, Gary. 2012. Europe and its Empires. From Rome to the European Union. Journal of Common Market Studies 50:1-20.

Marks, Gary, Tobias Lenz, Besir Ceka, and Brian Burgoon. 2014. Discovering Cooperation. A Contractual Approach to Regional International Organizations. Unpublished manuscript.

Marks, Gary, Liesbet Hooghe, Tobias Lenz, Jeanine Bezuijen, Besir Ceka, and Svet Derderyan. 2015. Scale and Community. The Design of International Organizations. Oxford: Oxford University Press.

Moravcsik, Andrew. 1993. Preferences and Power in the European Community. A Liberal Intergovernmentalist Approach. Journal of Common Market Studies 31:473-524.

Mueller, Dennis C. 2003. Public Choice III. Cambridge, M.A.: Cambridge University Press.

Ostrom, Elinor. 2005. Understanding Institutional Diversity. Princeton: Princeton University Press.

Peters, Dirk, Katja Freistein, and Julia Leininger. 2012. Theoretische Grundlagen zur Analyse internationaler Organisationen. In Handbuch Internationale Organisationen, Eds. Katja Freistein, and Julia Leininger, 3-27. München: Oldenbourg.

Pevehouse, Jon, Timothy Nordstrom, K. Warnke n.d. [2004], Intergovernmental Organizations, 18152000: A New Correlates of War Data Set. At http://www.correlatesofwar.org/.

Pollack, Mark A. 2003. The Engines of European Integration. Delegation, Agency, and Agenda Setting in the European Union. Oxford: Oxford University Press.

Powers, Kathy, and Gary Goertz. 2011. The Economic-Institutional Construction of Regions. Conceptualisation and Operationalisation. Review of International Studies 37:2387-2416.

Risse, Thomas. 2000. "Let's Argue!” Communicative Action in International Relations. International Organization 54:1-39.

Rixen, Thomas, and Bernhard Zangl. 2012. The Politicization of International Economic Institutions in US Public Debates. Review of International Organizations 8:1-25. 
Schimmelfennig, Frank, Berthold Rittberger, Alexander Bürgin, and Guido Schwellnus. 2006. Conditions for EU Constitutionalization. A Qualitative Comparative Analysis. Journal of European Public Policy 13:1168-1189.

Schmitter, Philippe. 1996. Examining the Present Euro-Polity with the Help of Past Theories. In Governance in the European Union, Eds. Gary Marks, Fritz W. Scharpf, Philippe C Schmitter and Wolfgang Streeck, 121-150. London and Thousand Oaks, CA: Sage.

Simon, Herbert. 1996. The Sciences of the Artificial. Cambridge, M.A.: MIT Press.

Snidal, Duncan. 1985. Coordination versus Prisoners Dilemma. Implications for International Cooperation and Regimes. American Political Science Review 79:923-943.

Tallberg, Jonas. 2010. The Power of the Chair. Formal Leadership in International Cooperation. International Studies Quarterly 54:241-265.

Vabulas, Felicity, and Duncan Snidal. 2013. Organization without Delegation. Informal Intergovernmental Organizations (IIGOs) and the Spectrum of Intergovernmental Arrangements. Review of International Organizations 8:193-220.

Wendt, Alexander. 1999. Social Theory of International Politics. Cambridge: Cambridge University Press.

Zamora, Stephen. 1980. Voting in International Economic Organizations. American Journal of International Law 74:566-608.

Zürn, Michael. 1992. Interessen und Institutionen in der Internationalen Politik. Grundlegung und Anwendung des situationsstrukturellen Ansatzes. Opladen: Leske and Budrich.

Zürn, Michael, Martin Binder, and Matthias Ecker-Erhardt. 2012. International Authority and its Politicization. International Theory 4:69-106. 


\section{Appendix I: 72 International Organizations (1950-2010)}

\begin{tabular}{|c|c|c|c|}
\hline Acronym & Name of IO & $\begin{array}{c}\text { General } \\
\text { purpose IO } \\
\text { in } 2010\end{array}$ & $\begin{array}{l}\text { Years in } \\
\text { Dataset }\end{array}$ \\
\hline Andean /CAN & Andean Community & $\checkmark$ & 42 \\
\hline APEC & Asia-Pacific Economic Cooperation & & 20 \\
\hline ASEAN & Association of Southeast Asian Nations & $\checkmark$ & 44 \\
\hline BENELUX & Benelux Community & $\checkmark$ & 61 \\
\hline BIS & Bank for International Settlements & & 61 \\
\hline CABI & $\mathrm{CAB}$ international & & 24 \\
\hline CARICOM & Caribbean Community & $\checkmark$ & 43 \\
\hline CCNR & $\begin{array}{l}\text { Central Commission for the Navigation of } \\
\text { the Rhine }\end{array}$ & & 61 \\
\hline CEMAC & $\begin{array}{l}\text { Central African Economic \& Monetary } \\
\text { Union }\end{array}$ & $\checkmark$ & 45 \\
\hline CERN & European Organization for Nuclear Research & & 57 \\
\hline CIS & Commonwealth of Independent States & $\checkmark$ & 19 \\
\hline $\mathrm{CoE}$ & Council of Europe & & 61 \\
\hline COMESA & Common Market for East/Southern Africa & $\checkmark$ & 29 \\
\hline ComSec & Commonwealth of Nations & $\checkmark$ & 46 \\
\hline EAC & East African Community & $\checkmark$ & 27 \\
\hline ECCAS-CEEC & $\begin{array}{l}\text { Economic Community of Central African } \\
\text { States }\end{array}$ & $\checkmark$ & 26 \\
\hline ECOWAS & $\begin{array}{l}\text { Economic Community of West African } \\
\text { States }\end{array}$ & $\checkmark$ & 36 \\
\hline EEA & European Economic Area & & 17 \\
\hline EFTA & Euro Free Trade Association & & 51 \\
\hline ESA & European Space Agency & & 31 \\
\hline EU & European Union & $\checkmark$ & 59 \\
\hline FAO & Food \& Agriculture Organization & & 61 \\
\hline GCC & Gulf Cooperation Council & $\checkmark$ & 13 \\
\hline GEF & Global Environmental Facility/ Fund & & 17 \\
\hline IAEA & International Atomic Energy Agency & & 54 \\
\hline IBRD & World Bank & & 61 \\
\hline ICAO & International Civil Aviation Organization & & 61 \\
\hline ICC & International Criminal Court & & 9 \\
\hline IGAD & $\begin{array}{l}\text { Inter-Governmental Authority on } \\
\text { Development }\end{array}$ & $\checkmark$ & 25 \\
\hline ILO & International Labour Organization & & 61 \\
\hline IMF & International Monetary Fund & & 61 \\
\hline IMO & International Maritime Organization & & 51 \\
\hline INTERPOL & International Criminal Police Organization & & 61 \\
\hline IOM & International Organization for Migration & & 56 \\
\hline ISA/ISBA & International Seabed Authority & & 17 \\
\hline ITU & International Telecommunication Union & & 61 \\
\hline Iwhale & International Whaling Commission & & 61 \\
\hline LAIA/ALADI & Latin American Integration Association & & 51 \\
\hline LOAS & League of Arab States & $\checkmark$ & 61 \\
\hline MERCOSUR & Common Market of the South & $\checkmark$ & 20 \\
\hline NAFTA & North American Free Trade Association & & 17 \\
\hline NATO & North Atlantic Treaty Organization & & 61 \\
\hline
\end{tabular}




\begin{tabular}{|c|c|c|c|}
\hline NordC & Nordic Council & $\checkmark$ & 59 \\
\hline OAPEC & $\begin{array}{l}\text { Organization of Arab Petroleum Export } \\
\text { Countries }\end{array}$ & & 43 \\
\hline OAS & Organization of American States & $\checkmark$ & 60 \\
\hline $\mathrm{OAU} / \mathrm{AU}$ & African Union & $\checkmark$ & 48 \\
\hline OECD & $\begin{array}{l}\text { Organization for Economic Cooperation \& } \\
\text { Development }\end{array}$ & & 61 \\
\hline OECS & Organization of Eastern Caribbean States & $\checkmark$ & 43 \\
\hline OIC & Organization of the Islamic Conference & $\checkmark$ & 41 \\
\hline OIF/ACCT & Francophone Community & & 41 \\
\hline OPEC & $\begin{array}{l}\text { Organization of Petroleum Exporting } \\
\text { Countries }\end{array}$ & & 51 \\
\hline OSCE & $\begin{array}{l}\text { Organization for Security \& Cooperation in } \\
\text { Europe }\end{array}$ & & 38 \\
\hline OTIF & $\begin{array}{l}\text { Intergovernmental Organization for } \\
\text { International Carriage by Rail }\end{array}$ & & 61 \\
\hline PCA & Permanent Court of Arbitration & & 61 \\
\hline PIF & Pacific Islands Forum & $\checkmark$ & 36 \\
\hline SAARC & $\begin{array}{l}\text { South Asian Association for Regional } \\
\text { Cooperation }\end{array}$ & $\checkmark$ & 25 \\
\hline SACU & Southern African Customs Union & & 42 \\
\hline SADC & Southern African Development Community & $\checkmark$ & 29 \\
\hline $\mathrm{SCO}$ & Shanghai Cooperation Organization & $\checkmark$ & 9 \\
\hline SELA & Latin American Economic System & & 45 \\
\hline SICA & Central American Integration System & $\checkmark$ & 59 \\
\hline SPC & South Pacific Community & $\checkmark$ & 61 \\
\hline UN & United Nations & $\checkmark$ & 61 \\
\hline UNESCO & $\begin{array}{l}\text { UN Education, Scientific, \& Cultural } \\
\text { Organization }\end{array}$ & & 61 \\
\hline UNIDO & UN Industrial Development Organization & & 26 \\
\hline UNWTO & World Tourism Organization & & 36 \\
\hline UPU & Universal Postal Union & & 61 \\
\hline WCO & World Customs Organization & & 59 \\
\hline WHO & World Health Organization & & 61 \\
\hline WIPO & World Intellectual Property Organization & & 44 \\
\hline WMO & World Meteorological Organization & & 61 \\
\hline WTO & World Trade Organization & & 16 \\
\hline
\end{tabular}

Seventy of the 72 IOs in the dataset are in the Correlates of War (COW) Dataset (Pevehouse et al. 2004). The Shanghai Cooperation Organization and the European Economic Area are not in the COW dataset, but meet five of the six criteria. IOs that do not meet the threshold but are in the COW dataset include the Association of African Trade Promotion Organizations (AATPO), which lacks a permanent secretariat, an annual meeting, and a website (and is a subsidiary of the African Union); the Australia-New Zealand-US Treaty Organization (ANZUS), which has two members and does not have a permanent secretariat, webpage or address; the Arctic Council, which had until 2011 a rotating secretariat of very small size. Several COW-listed IOs are subsidiaries of other organizations, such as the Andean Parliament, a consultative body to the Andean Community; the Nordic Council of Ministers, an executive body of the Nordic Council; or the European Central Bank, a European Union institution. 


\section{Appendix II: Coding Policy Scope}

The policy portfolio of each IO was assessed by two independent coders with a list of 25 policies in hand. This list was adapted from a classification scheme initially developed for the European Union by Lindberg and Scheingold (1970), and updated by Philippe Schmitter (1996) and Liesbet Hooghe and Gary Marks (2001). Coders were asked to code the policy responsibility of each IO in two ways: a) in what policies does the IO have substantial involvement, and b) of these policies, which policy constitutes the core activity of the IO in 2010 ? The Krippendorff's alpha among coders is 0.70 , which indicates reasonably high intercoder reliability.

\section{Agriculture}

2. Competition policy, mergers, state aid, antitrust

3. Culture and media

4. Education (primary, secondary, tertiary), vocational training, youth

5. Development, aid to poor countries

6. Financial regulation, banking regulation, monetary policy, currency

7. Welfare state services, employment policy, social affairs, pension systems

8. Energy (coal, oil, nuclear, wind, solar)

9. Environment: pollution, natural habitat, endangered species

10. Financial stabilization, lending to countries in difficulty

11. Foreign policy, diplomacy, political cooperation

12. Fisheries and maritime affairs

13. Health: public health, food safety, nutrition

14. Humanitarian aid (natural or man-made disasters)

15. Human rights: social \& labor rights, democracy, rule of law, non-discrimination, election monitoring

16. Industrial policy (including manufacturing, SMEs, tourism)

17. Justice, home affairs, interior security, police, anti-terrorism

18. Migration, immigration, asylum, refugees

19. Military cooperation, defense, military security

20. Regional policy, regional development, poverty reduction

21. Research policy, research programming, science

22. Taxation, fiscal policy coordination

23. Telecommunications, internet, postal services

24. Trade, customs, tariffs, intellectual property rights/ patents

25. Transport: railways, air traffic, shipping, roads

(26. Data collection, statistics, reports - coded separately) 


\section{Author contacts:}

\section{Tobias Lenz}

University of Göttingen

GIGA German Institute of Global and Area Studies

\section{Jeanine Bezuijen}

VU University of Amsterdam

\section{Liesbet Hooghe}

University of North Carolina, Chapel Hill

VU University of Amsterdam

\section{Gary Marks (corresponding author)}

University of North Carolina, Chapel Hill

VU University of Amsterdam

Email: Marks, Gary W <marks@unc.edu> 